УДК 821.164.41.09 Андрић, И. https://doi.org/10.18485/msc50.2019.1.ch39

Предраг Палавестра

\title{
АНДРИЋЕВ ДУХОВНИ ЛИК
}

\section{Поводом деведесетогодишњице рођења}

Позван сам да на овом угледном скупу слависта кажем неколико речи о Иви Андрићу, поводом деведесетогодишњице његовог рођења. Ту част заслужио сам, по свему судећи, тиме што сам не тако давно објавио неку врсту Андрићеве критичке биографије, ${ }^{1}$ где сам живот, духовни лик и стваралачко присуство писца тражио у његовоме тексту и где сам, упркос многим друкчијим очекивањима, нашао не само приповедача, хроничара, романописца и мудрог историчара, већ и скривеног песника. Затворен у себе и доста неповерљив према јавности, Андрић је, као и сви меланхолични песници, језгро своје душе чувао за себе, али ипак доста јасно и разговетно указао на пут којим се може ући у тајни, унутрашњи простор његовога духа, па и у његову мајсторску радионицу. О томе путу, заправо о тој уској и скривеној стази, која нас може довести до једног мало познатог Андрића, хтео бих овде да кажем неколико речи, подсећајући вас да је та стаза, наравно, она тајновита „вишеградска стаза” која је „испод свих друмова земље стално текла” видљива само за Андрића, и према којој је он целог живота „одмеравао свој корак и подешавао ход”.

Када се иде трагом те невидљиве вишеградске стазе, која води у детињство и младост, долази се до унутрашњег, скривеног Андрићевог лика и до једног од најзначајнијих кључева његове поетике. Долази се до тајнога слоја у његовоме делу, до само њему знане духовне галаксије, чије је обликовање и затварање пред туђим светом било започето још у првој младости. Из тога доба је остало врло мало сведочанстава, записа и података, тако да и неки узгредни списи, прве песме или писма, добијају вредност изузетно важних докумената првога реда. У њима је сачувано

${ }^{1}$ Скривени песник, Прилог критичкој биографији Иве Андрића, Београд, „Слово љубве”, 1981. 
много доказа о немиру и таложењу Андрићевог душевног садржаја управо у оном унутрашњем слоју који се постепено преображавао у песнички материјал и у часовима поверавања претварао у песнички текст.

Пут до Андрића, дакле, не води никаквим спољним, обасјаним и широким путевима којима се човек лако креће, већ углавном скровитим, невидљивим и тешко проходним врлетним стазама изнад дубоких и тамних понора. Са маском на лицу и са тајанственим, сакривеним садржајима у дну свога самотничког и неповерљивога света, Андрић је по много чему изразити пример песника отуђења. Његов духовни космос опстојава првенствено захваљујући сталном супротстављању, прожимању и допуњавању спољашњег и унутрашњег бића, захваљујући непрекидном превладавању монолошких форми и вечитом трагању за двојником у себи, за неким другим и друкчијим ја које се скрива у далеком и мрачном куту сопствене езгистенције. Као и код већине закопчаних, неповерљивих и осетљивих људи, код Андрића су два његова лика били различити и неусклађени, али су се на неким местима ипак додиривали и у одређеним приликама доста изједначавали. Пронаћи те тачке додира и поистовећености значило би утврдити животне чворове његове стваралачке психологије и приближити се разумевању крајње замршеног и компликованог механизма транспоновања унутрашњег, дубоко личног и изразито субјективно обојеног лирског света у објективизовану епску форму. Критичка биографија тражила је повратну спрегу између лирског и епског тока у Андрићевом делу, осматрала богатство облика и утицаја у односу између истинскога, скривенога песниковог бића (ја-за-себе) и човека присутног у причи као у огледалу (ја-за-другог). Пратила је путеве варке, значење маске и начине прерушавања; испитивала је корене и мотиве Андрићевог митотворства као облика естетичке организације несклада између унутрашњег и спољашњег света, као покушаја уметничког трансцендирања пролазних животних форми грађењем потпуно нове и самосталне галаксије.

Исповедни и контемплативни карактер Андрићеве лирике, са трансформацијом песничких облика од слободнога стиха ка прозном фрагменту, од језика поезије ка језику прозе, био је одраз једног врло компликованог духовног система. Променом поетских облика и претапањем песничких и прозних форми, Андрић је омогућио да његов лирски текст, наизглед хибридан и несталне, недефинисане структуре, обухвати неколико различитих видова стваралачког односа према свету. Контемплативни однос према свету дошао је до израза у рефлексивном исповедном тону, својственом песницима романтичарског кова, код којих су унутрашњи светови нека врста природне противтеже стварном свету јаве. 
Медитативна својства Андрићеве лирике, остварена у ктатким прозним формама дневничких записа, приближила су поетски текст приповедачком. Трансформацијом песама у прози у афористички фрагмент са наративним призвуком, добили су се не украси већ нова мисаона својства, проткана кроз сва Андрићева дела као златна нит мудрости на којој почива лирски слој његовог књижевног стваралаштва. Схваћена као један систем лирских вредности и облика, Андрићева лирика управо због тога има изузетан значај у процењивању његове поетике и његове философије, пошто се у лирском слоју, прожетом субјективним мисаоним и психичким преокупацијама, у часу најтежих сазнања, на самоме дну очаја, јавила и уобличила вера да се стварањем може превладати сама смрт и ублажити трагично осећање бесмисла. Андрићева лирика се потврђује као специфичан књижевни облик, као дело које се стално ствара и непрекидно дограђуje (work in progress). Унутрашњи духовни континуитет тога дела надокнађује извесну привидну недовршеност, формалну разноверност и нејединство израза. Лирика је Андрићевом делу монолитан и чврст, динамичан и животни слој, који сталношћу и непрекидним обнављањем сведочи о трајним, мада понекад пригушеним и скривеним, поетским својствима текста, о јачини лирског сензибилитета и чудесно отпорној усамљеничкој визији света. Читавога живота лирика му је, очигледно, служила као нека врста медија за властита поверавања и провере, као субјективни коректив који помаже да се у епском сагледавању историје не изгуби и не заборави мала људска мера, без које све ствари у животу добијају чудовишне облике. Не дозвољавајући годинама да се лирика скупи и објави, Андрић се није одрицао своје мале личне мистике. Као да није хтео да једној већ дефинисаној и заокруженој епској целини додаје варљиву и несталну маглину личних расположења и слутњи, он је интимну песничку исповест чувао за себе.

Субјективни поетски и лирски напони, скривени иза приче, били су претекст за реалистичку приповетку, која се на разне начине трудила да буде што објективнија, да истинито дочара историјску илузију и да исповест меланхоличног песника претвори у казивање поузданог сведока. Пригушеним гласом човека који говори из сенке и из прикрајка, али који добро познаје и разуме сва скривена и необична знамења живота, Андрић је својим интимним расположењем, лирским стањем духа, као ситним сребрним прахом, прекривао сваку реч, сваки исказ, свако сведочење. Субјективно искуство живота он је исповедао кроз песму, лирски запис, успомену, есеј, приповетку и историјску хронику, немајући снаге да до краја сакрије чињеницу да је код њега готово све прожето и испуњено истим тихим, уздржаним тоном личног поверавања и ис- 
креног преношења стеченог искуства, у коме се, и поред истинитости и уверљивости чврсте, добро саграђене реалистичке приче, ипак задржало много личнога става и личнога виђења.

Повучена позиција приповедача била је стилским и тонским нијансирањима, неприметним навођењем читаоца на смер идеја, и врло карактеристичним успореним и једноличним ритмом објективизоване реченице, махом искоришћена као доказ истинитости исказа и неутралног става летописца, који поуке историје и живота бележи као окоштало сопствено искуство. Исповедајући то искуство, које кроз причу подиже до степена пуне реалистичке уверљивости, Андрић је знао да, по правилу, приповедање делује истинитије уколико је приповедач више повучен, и да се пригушивањем, гашењем, па чак и потпуним отклањањем наметљивог личног тона и изразитије личне боје лакше и потпуније постиже ефекат прихватања исказа, ма колико да је исказ од почетка био и остао субјективан. Као сви прави мајстори приче, он је тиме постизао да његова реч буде прихваћена као реч крунскога сведока, као онолико пуна истина колико је човеку дато да пуну истину види, доживи и схвати. Његово лично виђење постало је опште. За меланхоличну и сетну, напаћену и самотну душу егоцентричнога песника нема и не може бити већега блаженства. Грубо и неправедно одгурнут у страну, на саму ивицу живота, он се у живот враћа као носилац светлости, као демијург и творац истине, провиђењем одређен да занавек траје и зрачи топлином и сјајем свога Богу наличног духа и образа.

Пренесена у причу и уплетена у фабулу привидно објективизована реалистичком техником казивања, са спољне стране пажљиво очишћена од свих остатака и наноса личнога приступа и виђења, субјективна нота Андрићева губила се у подземним скровиштима нове стварности књижевнога дела, задржавајући ипак, до последњега крајичка, отисак песниковог лика на свему што је прошло кроз његову душу, кроз визију и машту и кроз стваралачки дух градитеља. Зато се пажљивим испитивањем у Андрићевом делу може установити постојање једног скривеног међупростора између лирског и епског слоја, међупростора испуњеног гипким, прелазним и алтернативним формама приповедачко-поетскога текста. По својим природним својствима тај текст је подједнако близак и краткоме песничком запису, бриткој рефлексији, исповедној прози интимнога дневника, као и причи коју, као сећање, приповедач саопштава у првоме лицу, уклањајући на тренутак кулисе безличне објективности којима је скривао присуство личнога става и искуства у једној причи испричаној пред судом вечности. Лирски субјективизам претапао се у сећање и исповедање, у захвалну и прикладну наративну форму присног 
поверавања у коме су се, услед појачаног личног ангжовања наратора, jaчег загревања интимистичкога текста и изразитије субјективне боје, песничке форме лако и природно комбиновале с приповедачким. Обриси реалности растапали су се и губили у измаглици субјективнога виђења, помућеног силином доживљаја, издвојеним и косим углом посматрања и интимном психичком напрегнутошћу. Привидно смирен и уздржан у сведочењу о себи самоме, и о ономе што је непосредно задирало у скривену приватну сферу његовог романтично-лирског поимања света, Андрић је уз помоћ алтернативних форми понекад врло смело мењао рационалну и логичку структуру класичног приповедачког реализма и стварао једну друкчију, сложенију и богатију прозу модернога типа. Она се и својим садржајем, и својим стилом, и својим облицима уздиже у горње и више области савременог реализма и слободне стваралачке имагинације, досежући и у сфере метафизике.

Елементи поетске фантастике и песничког ирационализма у метафизичким прозама Андрићевим обезбедили су гипкост алтерантивне приповедачке форме, примењене у свим оним случајевима када је под притиском унутрашњих поетских напона морала бити измењена перспектива приповедања и када је деловање лирске енергије, романтичарске имагинације и себичног индивидуализма условљавало промену реалистичке форме и преобржај приповедачких структура. Иако је параболом, о Аски и вуку био испробао и жанр алегоричне фантастичне приче о животињама, Андрић је своје одступање од класичне реалистичке приче најизразитије остварио у алтернативним формама прелазног, отвореног и затвореног типа, не залазећи сувише дубоко у област књижевне фантастике. Задржао се поглавито на трима главним типовима фантастичне приче: на причама о утварама и аветима, на причама о привиђењима, сновима, опсесијама и предсказањима, и на психолошкој причи о духовима. Разлог за уздржаност могао је бити двојак. Ти жанрови књижевне фантастике пружали су, пре свега, идеалне техничке услове за примену алтернативне форме као прелазног облика између прозе и поезије, између реалистичке и романтичарске приче, између епске и лирске нарације, између приповедања и исповедања. Истовремено, у тим жанровима најлакше се могао променити положај приповедача увођењем или уклањањем посредника, без кога је, када је била писана у првом лицу, прича имала сасвим лични исповедни тон и у пуној мери била зависна од интимистичкога претекста. Основа читаве Андрићеве песничке галаксије концентрисана је око три кључне тачке - око лирског, метафизичког и медитативног језгра, чије се зрачење на безброј начина, различитим замршеним и невероватним путевима, допуњује и преплиће с епским си- 
стемима Андрићевог дела, чинећи га крајње слојевитим и разноврсним. Варка је утолико већа што само дело представља замку за читаоца, који, заведен причом, понекада остаје изван правог, унутрашњег тока, изван свих у причу уплетених интроспективних поетских садржина и значења. Служећи се варком, писац је скривао прави траг, трудећи се да што дуже остане неометан у поседу сопствене тајне и приватне мистике.

Добро смишљена варка имала је изгледа на успех: с једне стране, игра прерушавања и тематизовања давала је веће могућности слободе у контрастирању унутрашњег и спољашњег света; с друге стране, тиме се ширило и обогаћивало поље дотад углавном редуковане комуникације и стварала се основа за дограђивање комуникационих система и комбиновање различитих гласова и перспектива. На трећој страни, отварала се могућност да се монолошка форма замени дијалогом и да се развију перспективе приповедања, што је такође одговарало смеру општег духовног кретања песникове галаксије од затворених унутрашњих простора и егоцентричног субјективизма ка отвореним пространствима објективнога света, историје и друштвенога морала заједнице. У новој ситуацији писац може да се скрива и испод маске на сопственоме лицу и иза свога јунака, који јесте ауторова слободна творевина и његова слика и прилика, али не и са̂м аутор, већ биће за себе.

Тако се долази до неочекиваног закључка да је Андрићев положај као приповедача у много чему налик на положај фра-Петра, који се у Проклетој авлији скрива иза приче у причи, и то приче из друге или из треће руке, дакле у унутрашњем, скривеном и неприступачном слоју, близу самога језгра, као забрањеног светилишта и неприкосновеног простора песникове пуне, божанске слободе, каквом располаже само свемогући Творац. Састављена од делова казиваних у различитим приликама, а скупљена у целину и испричана тек после фра-Петрове смрти, када ни опрез ни тајна више нису имали никаквога смисла и када се са голом истином могло изаћи на светло дана, фра-Петрова слојевита затворска прича, са јасним митским елементима у себи и са туробним поукама људске историје, својом оквирном формом, као битним чиниоцем андрићевске приповедачке структуре, указује на повучени положај приповедача. Приповедач (фра-Петар), иако и сам уплетен у причу и непосредно драматизован, ослања се у причи на казивање сведока (Хаима) и на исповест протагонисте (Ћамила), тако да се, посредним путем, монолошко казивање претвара у вишегласни дијалог људи који разговарају. Самим тим, променом положаја променила се и перспектива приповедања: са становишта тзв. селективног, односно мултиселективног свезналаштва, писац је прешао на становиште неутралног свезналице, које је пружало 
већу слободу за рад маште и широко пространство за слободно руковање грађом, односно обезбеђивало потпуну сигурност скривеног и невидљивог луткара, који иза сцене управља кретњама и гласом марионете. Оквирна прича, која је Андрићу неколико пута послужила као сигурно и захвално средство заштите, нарочито онда када је, као у Разговору са Гојом, излагао теоријска начела своје поетике, било када је, у посредној форми, саопштавао трагично искуство појединца изложеног насиљу историје, та прича управо код неповерљивих, закопчаних и интровертних писаца, склоних самопосматрњу и тихом исповедању, понекада може да послужи као маска за праву реч, као варка или нека врста проширене метафоре. У тој и тако структурираној причи може се препознати или део скривеног ауторовог света или нешто од његовога начина мишљења, понашања или приповедања.

Из скривеног лирског језгра развила се читава Андрићева књижевност заснована на поетском, митском и историјском искуству, увек изнова мерена и проверавана дужином мистичне „вишеградске стазе”, као сталног духовног и моралног коректива. Гледано споља, та нова стварност естетичког порекла и типа ослоњена је, у Андрићевом случају, највећим делом на историјску грађу и традиционално народно предање; главно својство мита њој, међутим, даје садржај песникове душе, његов праисконски страх од историјског искуства, његова метафизичка и религиозна слутња вечности, космичкога тајанства и једне коначне надземаљске правде. Она живот ублажава сном, а сан изједначује са смирењем и благим, нечујним и неприметним преласком у непостојање и блаженство смрти. Скривени есхатолошки садржај унутрашњег слоја у његовом делу показао је да је тзв. главни субјект тога дела, обузет идејом вечности и узвишене, апсолутне праведности и да, управо због тога метафизичкога садржаја, он стоји у непосредној егзистенцијалној спрези са тајном Времена. Тако се уз Андрића као сенка опет јавља лик фра-Петра, који је био сахачија на гласу и у чијој ћелији је увек „било великих и малих часовника, који су цео простор испуњавали својим једномерним шумом и повременим искуцавањем часова." Много пажљивије него ишта друго, у својој испосничкој ћелији самоће Андрић је пратио, осматрао и испитивао видове и односе три главна тока времена: поетско, митско и историјско време, проверавао је сва њихова разноврсна и невероватна дејства и бивао све сигурнији у своме дубоко пригушеном уверењу да је Време део божанског мистерија, коначна мера, поравнање, казна и утеха свеукупнога постојања, последње уточиште свих појава и свих ствари.

Унутрашњи простор у Андрићевом књижевном делу, у коме се скрива песников прави лик, испуњен је неспокојством и зебњом чове- 
ка који је дошао на домак спознаје о великој тајни свемоћног и неизмерног времена, човека суоченог са ништавилом и одређеног свешћу о скучености људске моћи пред силином и снагом пролазности, смрти и нестајања. Тај човек је обузет визијом отвореног бескраја, у коме се песничко субјективно време и објективно време историје стапају у јединствену надтемпоралност мита о вечитој и неизменљивој самоћи човека пред Богом. Своме положају људски дух се супротставља једино новим чином стварања, премештањем свога скривеног личног богатства у нову, дотад непостојећу стварност уметничког дела, у коме се човек остварује предавањем садржаја своје душе другоме. На тај начин човек прекорачује границе времена и наставља да живи све док му се глас разазнаје у људској заједници. 